\title{
Budaya Paleolitik Pegunungan Serayu Di Wilayah Kabupaten Banyumas
}

\section{Muhammad Hidayat}

Keywords: lithic, adze, axe, chopper-chopping tools, stone tools, typology, function, flakes

\section{How to Cite:}

Hidayat, M. (2003). Budaya Paleolitik Pegunungan Serayu Di Wilayah Kabupaten Banyumas. Berkala Arkeologi, 23(1), 1-11. https://doi.org/10.30883/jba.v23i1.856

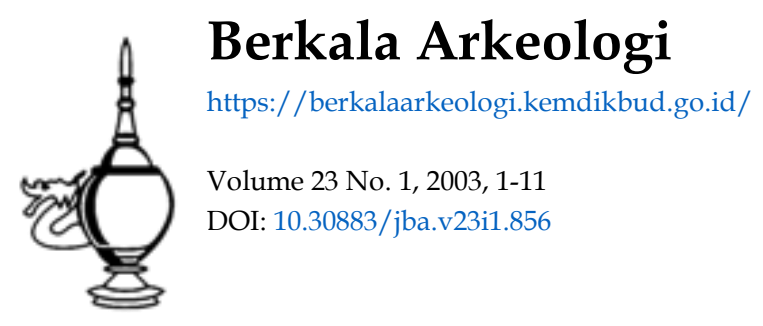




\title{
BUDAYA PALEOLITIK PEGUNUNGAN SERAYU DI WILAYAH KABUPATEN BANYUMAS
}

\author{
Muhammad Hidayat
}

\begin{abstract}
rtefak Paleolitik di Banyumas
D Di Pulau Jawa, dari beberapa penelitian yang telah dilakukan diketahui bahwa 1 sebagian besar budaya paleolitik ditemukan di lingkungan aliran sungai yang berada di pegunungan, seperti di Pegunungan Selatan Jawa dan di beberapa wilayah yang berada di Pegunungan Serayu. Khususnya di Pegunungan Serayu, selama di ketahui bahwa pada beberapa aliran sungai di wilayah Kabupaten Kebumen dan Purbalingga telah ditemukan alat-alat paleolitik. Mengenai budaya paleolitik yang terdapat pada lingkungan Pegunungan Serayu di kedua wilayah kabupaten ini telah banyak dibahas (R.P. Soejono, 1984; T. Simanjuntak dkk. 1984;. R. Ahmad Rosyadi Widayat, 2002).
\end{abstract}

Ternyata Budaya paleolitik yang berkembang di lingkungan Pegunungan Serayu sebarannya sampai di wilayah Kabupaten Banyumas. Hal ini ditunjukkan oleh beberapa tinggalan alat paleolitik.yang diperoleh melalui survei permukaan. Namun alat paleolitik yang ditemukan kuantitasnya sangat kecil. Selama survei pada aliranaliran sungai di wilayah Banyumas yang berhulu dan berada di lingkungan Pegunungan Serayu hanya memperoleh lima artefak paleolitik. Kelima artefak ini ditemukan pada aliran Sungai Sumpiuh dan Somagede. Adapun secara rinci masingmasing tipe alat-alat litik tersebut dapat digambarkan sebagai berikut.

\section{A. Kapak Perimbas}

Kapak perimbas yang ditemukan selama survei sejumlah 2 buah, yaitu ditemukan pada aliran Sungai Sumpiuh yang melintas di Dusun Karangduwur, Desa Selanegara, Kecamatan Sumpiuh, dan pada aliran Sungai Somagede yang melintas di Dusun Tanubaya, Desa Somagede, Kecamatan Somagede. Kapak perimbas dari aliran Sungai Sumpiuh berbahan rijang abu-abu, sedang kapak perimbas dari aliran Sungai Somagede berbahan andesit. Ukuran kapak perimbas dari aliran Sungai Sumpiuh lebih besar, yaitu panjang $11,9 \mathrm{Cm}$, lebar $12 \mathrm{Cm}$, dan tebal 7,8 Cm, sementara kapak perimbas dari aliran Sungai Somagede berukuran panjang $11,7 \mathrm{Cm}$, lebar $8 \mathrm{Cm}$, dan tebal $5,2 \mathrm{Cm}$.

Kedua kapak perimbas tersebut dibuat dari serpih yang cukup tebal, dengan dataran pukul yang lebar. Pada bagian dorsal terdapat faset-faset yang merupakan bekas pangkasan (penyerpihan). Faset pada dorsal ini tampak lebih jelas dan lebih banyak pada kapak perimbas dari aliran Sungai Somagede. Dorsal kapak perimbas dari 
Sungai Somagede hampir semuanya dipenuhi faset, dan korteknya hanya tinggal sebagian kecil. Sementara faset pada dorsal kapak perimbas dari Sungai Sumpiuh hanya sedikit serta pendek dan sempit, dan hanya terdapat di dekat bagian tajaman. Oleh karenanya kortek pada kapak perimbas ini masih memenuhi hampir semua bagian dorsal. Pangkasan pada dorsal yang meninggalkan faset tersebut dibuat untuk mendapatkan tajaman yang diinginkan, dan pangkasan ini dilakukan sebelum serpihan tebal ini dilepaskan dari batu intinya. Bentuk tajaman kapak perimbas berbahan andesit cembung dengan sudut tajaman yang cukup terjal, sedang bentuk tajaman kapak perimbas berbahan rijang juga cembung dengan sudut tajaman yang lebih landai.

Kondisi kapak perimbas berbahan andesit cukup aus dan telah mengalami pembundaran, sehingga sudut-sudut faset maupun bagian tajaman telah tumpul. Demikian pula bekas pakai yang berupa perimping maupun pecah-pecah pada bagian tajaman yang umum dijumpai pada alat litik, sudah tidak tampak pada kapak perimbas ini karena kondisi yang telah aus tersebut. Pada kapak perimbas ini belum tampak adanya patina yang menempel. Sementara kapak perimbas yang berbahan rijang, kondisinya masih cukup bagus (belum begitu aus dan membundar). Sudut-sudut fasetnya masih tajam, sedang bagian tajamannya telah tumpul, berperimping, dan pecah-pecah akibat penggunaan (benturan) yang cukup keras dan intensif. Walupun secara umum kondisinya masih bagus, namun artefak ini telah mengalami patinasi dalam tingkat sedang.

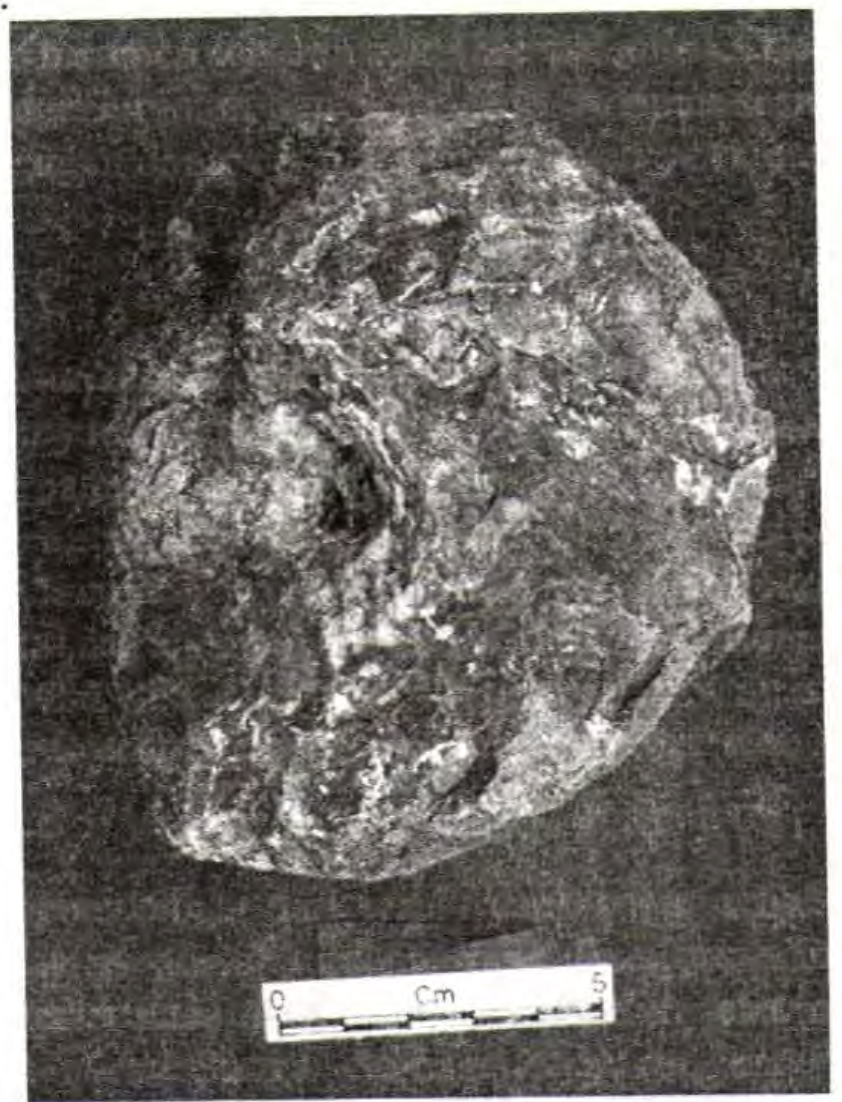




\section{B. Kapak penetak}

Satu-satunya kapak penetak yang ditemukan selama survei adalah kapak perimbas dari aliran Sungai Sumpiuh yang melintas di Dusun Karangduwur, Desa Selanegara, Kecamatan Sumpiuh. Kapak penetak ini dibuat dari bahan rijang abu-abu, dan berukuran panjang $11 \mathrm{Cm}$, lebar $12,1 \mathrm{Cm}$, dan tebal $8,1 \mathrm{Cm}$. Kondisi artefak sudah aus, membundar, dan seluruh permukaannya telah dipenuhi oleh patina.

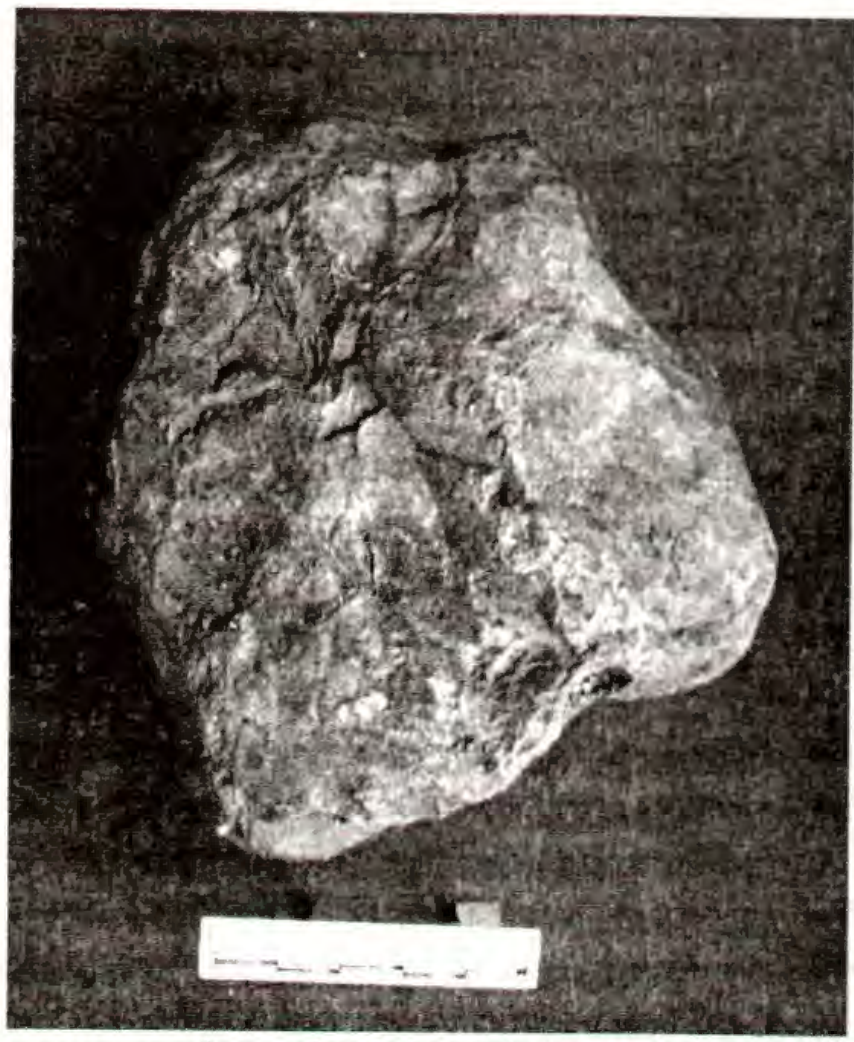

Kapak penetak dari aliran Sungai Sumpiuh ini dibuat dari kerakal yang seluruh permukaannya telah dipangkas sehingga meninggalkan faset-faset pada seluruh permukaan, dan kortek telah hilang sama sekali. Pada bagian proksimal terdapat faset besar/lebar dan datar yang menunjukkan bahwa bagian proksimal kapak ini sengaja dipotong dan didatarkan untuk mempermudah dan memperenak penggunaan alat tersebut. Kapak penetak tersebut mempunyai tajaman berbentuk meruncing dengan sudut yang sedang. Pada bagian tajaman maupun pada beberapa sudut-sudut pangkas-an terdapat perimping maupun luka berupa pecah-pecah/retak.Hal ini menunjukkan bahwa dalam menggunakan alat ini tidak hanya dengan bagian tajaman yang utama (yang sengaja dibuat), namun juga memanfaatkan bagian sudut-sudut pangkasan yang telah tajam.

\section{Alat Serpih}

Seperti diketahui bahwa selama survei telah ditemukan 2 buah alat serpih. Alat-alat serpih tersebut masing-masing ditemukan pada aliran Sungai Sumpiuh yang melintas di Dusun Karangduwur, Desa Selanegara, Kecamatan Sumpiuh dan aliran Sungai Somagede yang melintas di Dusun Tanubaya, Desa Somagede, Kecamatan Somagede. Kedua serpih ini dibuat dari bahan andesit. Ukuran masing-masing alat serpih tidak sama, Alat serpih dari aliran Sungai Sumpiuh berukuran panjang 10,7 Cm, lebar 14,5 $\mathrm{Cm}$, dan tebal 3,9 $\mathrm{Cm}$ sedang alat serpih dari aliran Sungai Somagede berukuran panjang $9,1 \mathrm{Cm}$, lebar $5,7 \mathrm{Cm}$, dan tebal $2,6 \mathrm{Cm}$. 


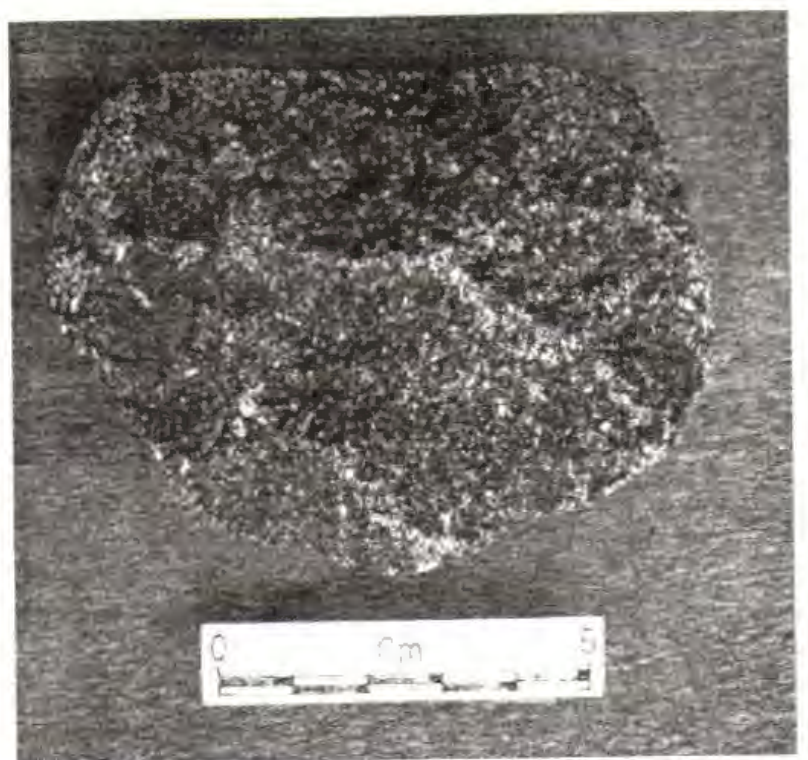

Kondisi kedua alat serpih yang ditemukan tersebut telah cukup aus dan telah mengalami pembundaran, namun patinasinya baru tingkat awal. Pada kedua alat serpih ini memiliki dataran pukul yang cukup lebar, dan pada bagian dorsalnya terdapat faset-faset bekas pangkasan yang ditujukan untuk mendapatkan tajaman pada alat tersebut. Bentuk tajaman pada alat serpih cenderung cembung. Tajaman pada alat serpih dari Sungai Sumpiuh terdapat pada ketiga sisinya, selain pada sisi proksimal. Sementara tajaman pada alat serpih dari Sungai Somagede hanya pada satu sisi. Kemiringan/sudut tajaman pada kedua alat serpih ini relatif landai. Oleh karena kondisinya yang telah aus, pada bagian tajaman maupunh sudut-sudut faset pada alat serpih tersebut telah tumpul. Namun demikian pada bagian tajaman masih terlihat adanya perimping-perimping yang diduga akibat penggunaan.

\section{T} ingkungan Keberadaan Alat Paleolitik di Banyumas

Pegunungan Serayu (Selatan) merupakan barisan perbukitan yang memanjang dari Banyumas hingga Purworejo. Seperti telah disebutkan bahwa alat-alat litik yang ditemukan dalam survei di wilayah Kabupaten Banyumas, semuanya berada pada aliran sungai yaitu Sungai Sumpiuh dan Sungai Somagede. Pada kedua sungai ini banyak terdapat endapan jenis batuan yang umum digunakan sebagai bahan alat litik tersebut.

Pada aliran Sungai Sumpiuh banyak terdapat endapan batu jenis andesit yang berukuran kerakal, berangkal, dan bolder. Namun sebagian besar endapan batu andesit ini berukuran kerakal. Selain batu jenis andesit yang mendominasi endapan pada aliran sungai tersebut, terdapat pula endapan kerakal rijang dalam kuantitas yang sangat sedikit. Endapan batuan pada aliran Sungai Somagede di lokasi pengamatan, keseluruhannya dari jenis andesit. Ukuran batu andesit yang terendapkan pada sungai ini adalah kerakal, berangkal, dan bolder, namun didominasi oleh kerakal. Ukuran batu andesit yang terendapkan di lokasi ini mulai dari kerakal hingga bolder. Keberadaan artefak alat litik yang ditemukan pada kedua aliran sungai tersebut bercampur dengan endapan batu dari berbagai ukuran tersebut. 
Bagian aliran pada kedua sungai yang mengandung alat litik seperti yang telah ditemukan, berada pada daerah bertopografi dengan kemiringan cukup landai dan cenderung relatif datar. Menilik pada kondisi alat-alat litik yang ditemukan, yaitu telah mengalami keausan dan pembundaran diperkirakan artefak tersebut berasal dari lokasi yang cukup jauh dari lokasi pengendapan terakhir (lokasi penemuan). Diperkirakan lokasi asal alat-alat litik tersebut berada pada lokasi di sekitar aliran sungai di bagian yang dekat dengan areal yang bertopografi miring (lereng). Dugaan ini juga didasarkan pula pada kenyataan bahwa di lokasi yang dekat dengan dua bentuk lingkungan yang berbeda (dataran dan lereng) akan lebih mudah diperoleh sumberdaya alam dengan variasi yang tinggi, khususnya flora dan fauna sebagai sumber makanan. Pada lokasi seperti itu diperkirakan manusia prasejarah tradisi paleolitik lebih banyak beraktivitas, khususnya dalam mencari dan mengolah makanan.

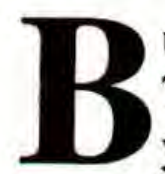
udaya Paleolitik Pegunungan Serayu Telah disebutkan bahwa survei permukaan di wilayah Kabupaten Banyumas yang berada di lingkungan Pegunungan Serayu telah menemukan beberapa artefak litik yang mewakili budaya alat litik di wilayah tersebut. Alat-alat litik yang merupakan hasil budaya tradisi paleolitik tersebut berupa kapak perimbas, kapak penetak, dan serpih. Jenis bahan yang digunakan untuk pembuatan alat-alat adalah andesit dan rijang. Bahan semacam ini banyak ditemukan pada lingkungan penemuan alat tersebut. Mengacu pada keberadaan dataran pukul yang cukup lebar pada alat, khususnya pada kapak perimbas dan serpih, dalam proses pembuatan alat tersebut yaitu pada saat penyerpihan/pelepasan dari bahan yang besar (batu inti) digunakan teknik pukulan langsung (direct percussion). Selain itu apabila mengacu pada tingkat teknologi yang diterapkan untuk menghasilkan budaya fisik khususnya pada alat masif yang berupa kapak perimbas dan kapak penetak, diketahui terdapat dua tingkatan teknologi yang berbeda. Seperti diketahui bahwa teknik pembuatan kapak perimbas dengan kapak penetak berbeda. Untuk membentuk tajaman kapak perimbas cukup dari satu muka, sedangkan pada kapak penetak dilakukan pemangkasan pada kedua sisi mukanya. Teknik yang digunakan dalam pembuatan kapak penetak ini lebih sulit dibanding dalam pembuatan kapak perimbas. Apalagi dalam pembuatan kapak penetak yang ditemukan di wilayah Kabupaten Banyumas tersebut, terdapat beberapa pangkasan yang ditujukan untuk menghilangkan kortek dan membentuk kapak tersebut, sehingga teknologi kapak perimbas ini sudah menyerupai teknologi yang diterapkan pada kapak genggam. Sementara itu kondisi alat-alat litik yang pada umumnya telah aus dan membundar, menunjukkan bahwa alat-alat tersebut telah tertransportasi dari tempat yang lebih tinggi (dari arah hulu) sebelum artefak tersebut terendapkan terakhir kalinya di lokasi penemuan.

Hasil budaya paleolitik yang ditemukan di wilayah Kabupaten Banyumas tersebut mempunyai kesamaan dengan hasil budaya paleolitik yang ditemukan di wilayah lain 
dalam lingkungan maupun di luar lingkungan Pegunungan Serayu. Kesamaan tersebut terjadi pada tipe alat yang dihasilkan, teknologi yang dipakai, maupun kondisi alat pada saat ditemukan.

Pada aliran Sungai Kuning, Sungai Tambra, dan Sungai Laban yang melintas di wilayah Kecamatan Karanganyar, Purbalingga terdapat alat-alat litik dari tradisi paleolitik. Sebantak 46 alat paleolitik telah dikumpulkan dari ketiga aliran sungai tersebut yang 39 buah diantaranya berasal dari aliran Sungai Kuning, menunjukkan bahwa alat-alat litik tersebut berupa kapak perimbas, kapak penetak, proto kapak genggam, alat serpih, serut, dan gigantolith. Bahan alat dari jenis rijang hijau. Jenis bahan ini sangat banyak ditemukan di sekitar lokasi tersebut. Khususnya alat paleolitik yang masif ini dibuat dari fragmen atau serpih besar, dan pada kapak perimbas dan kapak penetak pada bagian dorsalnya masih banyak menyisakan kortek. Tajaman pada kedua tipe kapak ini dibentuk dengan pangkasan yang melebar dan dengan sudut tajaman yang sedang hingga terjal. Menilik pada teknologi pembuatan pada ketiga tipe kapak paleolitik yang ditemukan (kapak perimbas, kapak penetak, dan proto kapak genggam), diketahui terdapat tiga tingkatan kemajuan teknologi yang diterapkan dalam pembuatan alat litik. Bisa jadi tingkatan teknologi yang berbeda ini mengisyaratkan masa yang berbeda pula. Hampir semua artefak paleolitik dari ketiga aliran sungai tersebut telah mengalamai pembundaran. Kondisi ini menunjukkan bahwa alat-alat litik yang ditemukan tersebut telah tertransportasi dari tempat lain (dari arah hulu) sebelum pengendapan terakhir dan ditemukan (lihat T. Simanjuntak dkk. 1984).

Sementara itu di wilayah Kabupaten Kebumen yang berada di lingkungan Pegunungan Serayu, juga ditemukan beberapa alat-alat paleolitik. Lokasi penemuan alat-alat paleolitik ini berada di aliran Sungai Kenteng, Kedung Macan, Luk Ulo, dan Sungai Karanganyar (R.P. Soejono, 1984; R. Ahmad Rosyadi Widayat, 2002). Dari penelitian yang terakhir dilakukan (oleh R. Ahmad Rosyadi Widayat, Mahasiswa Jurusan Arkeologi UGM), pada aliran Kedung Macan, Luk Ulo, dan Sungai Karanganyar telah didapatkan 22 buah alat paleolitik. Artefak paleolitik yang ditemukan ini terdiri dari kapak perimbas, kapak penetak, serpih, bilah, serut, dan batu inti. Adapun alat tersebut berbahan jenis andesit, lempung silikaan, dan rijang. Bahanbahan sejenis ini terdapat pula pada aliran-aliran sungai tersebut. Khususnya pada alat masif seperti kapak perimbas dan kapak penetak, dibuat dari kerakal maupun dari serpih besar dan tebal. Pada beberapa alat masif mempunyai dataran pukul yang lebar. Keberadaan dataran pukul ini menunjukkan bahwa alat tersebut dibuat dengan menggunakan teknik pemukulan langsung (direct percussion) pada saat pelepasan bahan dari kerakal maupun bongkah. Kebanyakan alat litik kondisinya telah aus dan telah membundar, sehingga bagian tajamannya telah tumpul dan tanda-tanda bekas pemakaian yang berupa luka dalam bentuk pecah-pecah maupun perimping sudah tidak jelas lagi (lihat R. Ahmad Rosyadi Widayat, 2002). Kondisi yang telah aus dan 
membundar ini menunjukkan bahwa artefak tersebut telah mengalami gesekan dengan aliran air maupun materi lain pada saat proses pengendapan. Hal ini dapat memberi petunjuk pula bahwa lokasi awal (sebelum pengendapan terakhir dan ditemukan), artefak tersebut berasal dari lokasi ke arah hulu.

Budaya paleolitik seperti yang ditemukan pada lingkungan Pegunungan Serayu tersebut mirip dengan budaya paleolitik yang ditemukan di luar lingkungan Pegunungan Serayu, seperti yang ditemukan pada Daerah Aliran Sungai (DAS) Cilaca yang berada di wilayah Kabupaten Cilacap. Dari penelitian yang telah dilakukan terhadap 130 artefak paleolitik dari DAS Cilaca yang dijadikan sampel, diketahui sekumpulan artefak tersebut terdiri dari kapak perimbas, kapak penetak, proto kapak genggam, kerakal dipangkas, serpih-bilah, dan serut. Selain itu terdapat pula batu inti yang merupakan sisa pembuatan alat, terutama alat serpih-bilah.

Kesemua alat-alat paleolitik dari DAS Cilaca berbahan andesit. Jenis bahan ini banyak terdapat pada aliran sungai tersebut. Hampir semua alat dibuat dari serpihan kecuali pada proto kapak genggam yang dibuat dari kerakal. Pada umumnya alat-alat paleolitik tersebut masih menyisakan kortek dalam kuantitas yang cukup besar, bahkan pada kelompok alat serpih kandungan korteknya pada umumnya masih sekitar $90 \%$ dari permukaan dorsalnya. Dataran pukul pada alat-alat litik yang berbahan serpihan tampak sempit dan terkadang tidak jelas. Hal ini menunjukkan bahwa kebanyakan dalam proses pelepasan serpih dari bongkahan dilakukan dengan teknik block on block. Dugaan ini didukung pula oleh adanya kortek yang hampir memenuhi dorsal serpih yang dihasilkan. Kondisi alat, pada umumnya telah mengalami pembundaran dan keausan tingkat sedang hingga lanjut, dan beberapa di antara telah tertempeli patina yang cukup tebal (lihat Jatmiko dan D. Driwantoro, 1999). Pembundaran pada alat-alat litik ini menunjukkan bahwa artefak tersebut telah mengalami penggelindingan pada saat proses pengendapan terakhir. Khususnya pada proses pembuatan alat masif, terdapat perbedaan tingkat teknologi yang diterapkan pada ketiga tipe alat tersebut. Dalam proses pembuatan proto kapak genggam dibutuhkan teknik yang lebih tinggi dibanding pembuatan kapak penetak, dan apalagi pada pembuatan kapak perimbas.

\section{Dosisi Budaya Alat Litik Pegunungan Serayu dalam Perkembangan Paleolitik di Indonesia}

1 Budaya paleolitik merupakan budaya manusia tertua. Di wilayah Indonesia persebaran alat paleolitik ini sangat luas, dan eksistensinya sangat lama. Pada umumnya alat-alat paleolitik ini berkembang pada lahan yang terbuka dan di lingkungan sungai. Selama ini dikenal jenis-jenis/ tipe alat yang termasuk dalam tradisi paleolitik, diantaranya adalah kapak perimbas, kapak penetak, pahat genggam, proto kapak genggam, kapak genggam, serpih, bilah, dan serut. Khususnya pada alat 
masif ini terdapat perbedaan tingkat teknologi yang dipakai dalam pembuatan alat tersebut. Namun tidak diketahui secara pasti bahwa apakah perbedaan teknologi tersebut menunjukkan pada perbedaan masa perkembangannya atau berkembang pada masa yang bersama dan dikuasai oleh pendukung yang sama. Hal ini disebabkan kebanyakan alat-alat paleolitik dari berbagai tipe selalu ditemukan tercampur/bersamaan di permukaan dan tidak diketahui lagi posisi stratigrafinya seperti yang banyak ditemukan di Kawasan Pegunungan Selatan Jawa (Muhammad Hidayat, 1999/2000).

Permasalahan lain adalah menyangkut kronologi perkembangan alat paleolitik di hampir semua situs paleolitik di Indonesia. Hampir semua situs paleolitik sampai saat ini belum diketahui umurnya secara pasti. Pertanggalan mutlak terhadap alat-alat paleolitik yang ditemukan dalam penelitian hampir tak pernah dilakukan dan sangat sulit untuk dilakukan. Sebagai penyebabnya adalah konteks alat paleolitik yang ada dipermukaan sudah tidak jelas lagi karena telah terakumulasi dengan materi lain dari masa yang tidak diketahui. Selama ini hanya diketahui bahwa tradisi paleolitik di Indonesia berkembang sejak Kala Awal Plestosen Tengah hingga akhir Kala Plestosen Atas. Walaupun demikian, pada beberapa situs telah diketahui pertanggalan relatifnya berdasarkan pada posisi stratigrafi endapannya. Berdasarkan umur grenzbank diketahui bahwa paling tidak alat-alat paleolitik non masif di Situs Sangiran telah berumur 800.000 tahun (Harry Widianto, 1998). Sementara berdasarkan posisi teras sungai pengandung alat-alat paleolitik di lembah Sungai Baksoka, Pacitan diperkirakan bahwa tradisi paleolitik telah berkembang di lingkungan tersebut paling tidak sejak 281.000 tahun yang lalu (Muhammad Hidayat, 2002). Selain itu, berdasarkan pula pada posisi teras sungai pengandung alat-alat paleolitik yang banyak ditemukan pada aliran Sungai Oyo, Gunungkidul diperkirakan bahwa alat-alat paleolitik tersebut telah berkembang paling tidak sejak 90.000 tahun yang lalu (Harry Widianto, 1983).

Berkaitan dengan permasalahan kronologi perkembangan tradisi paleolitik di Indonesia tersebut, permasalahan serupa terdapat pula pada alat-alat paleolitik yang berkembang khususnya di wilayah Kabupaten Banyumas, dan pada umumnya di Kawasan Pegunungan Serayu. Tidak dapat diketahui secara pasti apakah kapak perimbas muncul dan berkembang terlebih dahulu daripada kapak perimbas atau berkembang secara bersamaan, dan kapan alat-alat tersebut mulai muncul. Berdasarkan tingkat kemajuan teknologi yang diterapkan dalam pembuatan kapak tersebut jelas menunjukkan perbedaan. Boleh jadi perkembangan kapak penetak terjadi lebih kemudian daripada kapak perimbas karena memiliki tingkat teknologi yang lebih maju. Sementara itu kronologi perkembangan kedua kapak tersebut maupun pada alat paleolitik lain yang ditemukan di Kabupaten Banyumas sangat sulit untuk dijawab. Seperti diketahui bahwa alat-alat paleolitik di wilayah ini ditemukan di permukaan tanpa konteks stratigrafi maupun artefak lainnya. Namun menilik pada 
teknologi yang digunakan dalam pembuatan alat khususnya pada alat masif, terdapat persamaan dengan teknologi yang berkembang di lembah Sungai Baksoka, sehingga ada kemungkinan bahwa masa perkembangan budaya paleolitik di Banyumas tidak jauh berbeda dengan masa perkembangan budaya paleolitik di lembah Sungai Baksoka.

\section{I} nteraksi Budaya Paleolitik dengan Lingkungan

Alat-alat paleolitik seperti yang ditemukan pada aliran Sungai di lingkungan Legunungan Serayu di Wilayah Kabupaten Banyumas yang terdiri dari kapak perimbas, kapak penetak, dan serpih merupakan alat yang bersifat teknis yaitu peralatan yang digunakan dalam kehidupan sehari-harinya. Hingga saat ini diyakini bahwa jenis artefak tersebut berkaitan dengan aktivitas perburuan dan pengumpulan makanan manusia pendukungnya. Fungsi masing-masing tipe alat-alat paleolitik tersebut secara pasti berkaitan dengan aktivitas tersebut belum dapat diketahui. Berdasarkan ukurannya, diperkirakan alat yang cukup besar dipergunakan untuk pekerjaan yang cukup berat seperti untuk memotong dan membelah benda-benda yang cukup keras. Sementara alat-alat yang berukuran relatif kecil dan tipis digunakan untuk memotong, mengiris, maupun menyayat benda-benda yang cukup lunak. Ada kemungkinan bahwa alat-alat paleolitik tersebut tidak berfungsi spesifik namun multi fungsi. Disamping berfungsi langsung sebagai alat perburuan, pengumpulan dan pengolahan makanan, alat-alat tersebut juga digunakan untuk membuat alat lain dari bahan berbeda, seperti kayu atau bambu misalnya.

Telah disebutkan bahwa keberadaan alat-alat paleolitik yang berada pada aliran sungai dengan kondisinya yang cukup aus dan telah membundar serta bercampur dengan materi endapan lainnya menunjukkan bahwa alat-alat tersebut telah tertransportasi dari lokasi lain. Kondisi ini sebenarnya menyulitkan untuk mengetahui lingkungan asalnya. Namun dapat diduga bahwa lokasi asal alat-alat paleolitik ini berasal dari lingkungan sungai, yaitu dari tempat yang lebih ke atas (ke arah hulu). Seperti diketahui bahwa alat-alat paleolitik di wilayah Kabupaten Banyumas ditemukan pada aliran sungai yang berada topografi yang relatif datar, sehingga dapat diperkirakan lokasi asal alat-alat ini pada aliran sungai di sekitar lahan yang bertopografi miring/lereng. Sementara itu adanya kesamaan jenis bahan alat dengan jenis batu yang terendapkan pada aliran sungai mengindikasikan bahwa alat-alat tersebut juga di buat di lingkungan sungai tersebut dengan memanfaatkan jenis batu yang terendapkan pada sungai tersebut. Petunjuk ini diperkuat dengan kenyataan bahwa di wilayah Kabupaten Cilacap maupun di Kabupaten Kebumen, selain ditemukan alat dan bahan, juga ditemukan batu inti serta batu dipangkas pada aliran sungai yang sama. Keberadaan batu inti dan batu dipangkas (diduga alat yang belum atau tidak jadi) ini jelas menunjukkan adanya aktivitas pembuatan alat pada lingkungan aliran sungai tersebut. Berdasarkan hal tersebut, yaitu keberadaan alat litik yang berfungsi teknis dan 
terendapkan bercampur dengan materi batuan yang jenisnya sama dengan bahan alat tersebut, memberikan gambaran bahwa di wilayah Banyumas khususnya pada lingkungan aliran Sungai Sumpiuh dan Somagede di sekitar lahan yang bertopografi lereng pernah terdapat aktivitas kehidupan masyarakat pendukung tradisi paleolitik. Masyarakat ini diperkirakan hidupnya masih sangat tergantung pada lingkungan alamnya. Mereka masih melakukan pengumpulan makanan maupun perburuan binatang. Lingkungan sungai dipilihnya untuk aktivitas dalam hidupnya karena lingkungan tersebut dapat memenuhi kebutuhan, seperti kemudahan mendapatkan makanan dan bahan alat (alat paleolitik).

Air merupakan kebutuhan vital bagi makhluk hidup, baik manusia, binatang, maupun tumbuh-tumbuhan, sehingga sumber air cenderung didekati oleh makhluk hidup. Oleh sebab itu pada lingkungan sungai banyak terdapat sumber bahan makanan manusia dengan variasi yang tinggi, baik dari jenis-jenis tumbuhan, binatang air, maupun binatang darat. Terlebih pada lingkungan sungai yang berdekatan dengan bentuk lingkungan (bentuk lahan) lain, seperti dataran maupun perbukitan/lereng. Pada masing-masing bentuk lingkungan/jenis habitat ini tentu terdapat kehidupan makhluk yang berbeda jenisnya, sehingga akan memperkaya variasi sumber bahan makanan manusia.

Sesuai dengan bentuk lingkungan yang dipilih, untuk mempertahankan kelangsungan hidup manusia akan beradaptasi dengan lingkungan tersebut dengan sarana budaya. Terkait dengan hal ini masyarakat prasejarah yang hidup pada lingkungan aliran Sungai Sumpiuh dan Somagede telah menghasilkan jenis-jenis alat litik. Jenis-jenis budaya fisik yang berupa alat-alat litik yang dihasilkannya ini sangat dipengaruhi oleh kebutuhan, kemampuan, dan lingkungannya, terutama sumber bahan alat tersebut. Karena berfungsi teknis yaitu terutama untuk mengeksploitasi sumberdaya makanan yang ada di lingkungannya, maka bentuk/jenis/tipe alat litik yang dihasilkan sangat mungkin dipengaruhi oleh variasi sumberdaya yang tersedia pada masa itu. Dalam membuat peralatan untuk eksploitasi sumberdaya tersebut jelas sangat dipengaruhi oleh kemampuan atau teknologi yang dimiliki pembuatnya. Seperti telah disebutkan bahwa di wilayah Kabupaten Banyumas terdapat dua tingkatan teknologi yang dikuasai masyarakat masa prasejarah dalam pembuatan alat litik, khususnya dalam pembuatan alat masif. Hal ini ditunjukkan adanya kapak perimbas dan kapak penetak yang dihasilkan di wilayah tersebut. Sementara itu dalam pembuatan alat tersebut sangat tergantung pada sumber bahan yang tersedia. Jenis-jenis batu yang digunakan sebagai bahan alat, menggunakan bahan yang tersedia pada aliran sungai seperti ditunjukkan oleh adanya kesamaan bahan pada alat dengan jenis batuan yang teredapkan pada sungai di lokasi penemuan alat tersebut. 


\section{KEPUSTAKAAN}

Ahmad Rosyadi Widayat, R., 2002. Keberadaan artefak Batu Paleolitik di Kawasan Pegunungan Serayu Selatan dan Faktor yang Mempengaruhinya, Skripsi Sarjana Fakultas Ilmu Budaya Universitas Gadjahmada Yogyakarta.

Harry Widianto. 1983. Paleolitik Kali Oyo dalam Kronologi Pertanggalan Plestosen, Skripsi Sarjana Fakultas Sastra Universitas Gadjahmada.

dkk., 1998. "Penelitian Situs Sangiran: Eksistensi Artefak pada Awal Kala Plestosen Tengah dan Stratigrafi Endapan Teras di Atas Seri Kabuh dan Seri Notopuro", Berita Penelitian Arkeologi No. 03. Yogyakarta: Balai Arkeologi Yogyakarta

Jatmiko dan Driwantoro, D., 1999. Laporan Penelitian Arkeologi, Eksplorasi Tinggalan Alat-alat Litik Kala Plestosen di Sekitar Daerah Aliran Sungai (DAS) Cilaca, Kabupaten Cilacap, Jawa Tengah. Bidang Prasejarah, Pusat Penelitian Arkeologi Nasional.

Muhammad Hidayat.2000. Laporan Penelitian Arkeologi Bentuk-bentuk Pemanfaatan Sumberdaya Alam Kawasan Pegunungan Selatan Jawa pada Masa Prasejarah. Yogyakarta: Balai Arkeologi Yogyakarta.

dkk., 2002 "Posisi Stratigrafi Budaya Pacitanian", Berita Penelitian Arkeologi No. 15. Yogyakarta: Balai Arkeologi Yogyakarta

Simanjuntak T, dkk, 1984. Laporan Penelitian Arkeologi, Ekskavasi Ponjen, Purbalingga, Jawa Tengah. Balai Arkeologi Yogyakarta.

Simanjuntak T, dkk., 1986. Laporan Penelitian arkeologi Limbasari, Berita Penelitian Arkeologi, No. 34. Jakarta: Proyek Penelitian Purbakala Jakarta, Departemen Pendidikan dan Kebudayaan.

Soejono, RP, ed., 1984. Sejarah Nasional Indonesia I. Jakarta: PN Balai Pustaka. 